\title{
Environmental awareness
}

Context is everything for cells and, in addition to the importance of finding an appropriate blood supply (see Milestone 7), tumorigenic potential will often only be realized when cells find themselves in a tissue environment that they can subvert to their advantage. This phenomenon was first clearly noted in the 1970s, although it was decades before the cellular basis was uncovered.

In 1975, Beatrice Mintz and Karl Illmensee asked what would happen if mouse tetracarcinoma cells were placed in a 'normal' environment. They took the tetracarcinoma cells from embryoid bodies in vivo, and injected them into developing mouse blastocysts. Surprisingly, normal mice were born with no evidence of tumours. When the authors looked more closely, they found that tumour-derived cells were present in large numbers and contributed to several unrelated tissues, the most notable being functional spermatozoa. From this, Mintz and Illmensee concluded that the tumour cells were developmentally totipotent and could revert to normal behaviour in the appropriate environment. At the time, they also speculated that the original tumorigenic state might not involve a mutation.

This study was to have a strong influence on Mina Bissell. Inspired by this mysterious behaviour of tumour cells, Bissell began to focus her own research on the influence of the microenvironment. In 1984, she published a study, together with David Dolberg, showing that the ability of Rous sarcoma virus (RSV) to induce tumours was also context dependent. The tumour-inducing behaviour of RSV

\section{"These experiments form the groundwork for our current understanding that the environment in which cells are growing can influence the expression of the transformed phenotype" Sara Courtneidge}

when injected into the wings of newly hatched chicks was already known, and the viral gene $\mathrm{v}$-s $r c$ had been identified as the sole culprit.

What Bissell found, however, was that if RSV was injected into 4-day-old embryos, no tumours were produced, despite the spread of RSV infection throughout the embryo and active v-Src expression. Furthermore, if the infected embryonic cells were isolated and grown in culture, they now became transformed. So, something about the environment of the embryos was able to block tumorigenesis, despite the presence of $\mathrm{v}$-Src. The following year, her group went on to show that wounding was one important influence on the ability of a cell to succumb to tumorigenesis. When RSV was injected into a chick wing to produce a local tumour, a second tumour would only be seen if a wound was simultaneously induced at a remote site. The Bissell group later found that the factor responsible was transforming growth factor- $\beta$ (TGF- $\beta$ ) - an early and surprising demonstration of the dual action of this cytokine.

It is only during the past 10 years that we have begun to understand the molecular basis for how the local tissue environment, and processes such as inflammation and infection, can influence tumorigenic cells. For example, in 1997, Bissell and colleagues showed that blocking integrin function was sufficient to revert the malignant phenotype of human breast cancer cells both in culture and in vivo. Others, including the groups of Luis Parada and Harold Moses, were able to show in mouse models that genetic alterations in cells of the tumour microenvironment contribute to, and can even be sufficient for initiating, the development of cancer.

Alison Schuldt, Senior Editor, Nature Cell Biology

\section{References and Iinks}

ORIGINAL RESEARCH PAPERS Mintz, B. \& llimensee, $\mathrm{K}$. Normal genetically mosaic mice produced from malignant teratocarcinoma cells. Proc. Natl Acad. Sci. 72, 3585-3589 (1975) | Dolberg, D. S. \& Bissell, M. J. Inability of Rous sarcoma virus to cause sarcomas in the avian embryo. Nature $\mathbf{3 0 9}, 552-$

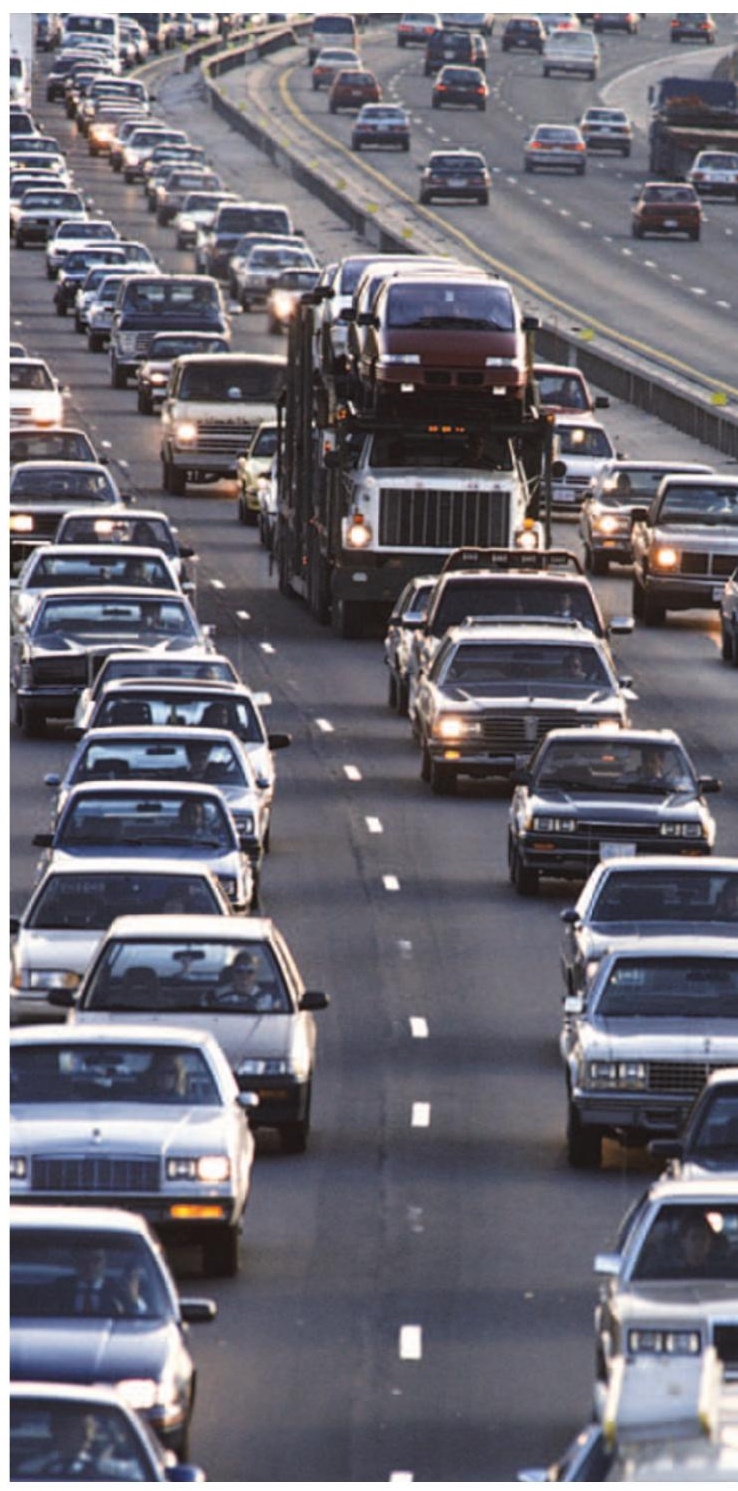

556 (1984) | Dolberg, D. S., Hollingsworth, R., Hertle, M. \& Bissell, M. J. Wounding and its role in RSV-mediated tumor formation. Science 230, 676-678 (1985) | Weaver, V. M. et al. Reversion of the malignant phenotype of human breast cells in three-dimensional culture and in vivo by integrin blocking antibodies. J. Cell Biol. 137, 231-245 (1997) | Sieweke, M. H. Thompson, N. L., Sporn, M. B. \& Bissell, M. J. Mediation of wound-related Rous sarcoma virus tumorigenesis by TGF- $\beta$. Science 248, 1656-1660 (1990) | Zhu, Y. et al. Neurofibromas in NF1: Schwann cell origin and role of tumor environment. Science 296, 920-922 (2002) | Bhowmick, N. A. et al. TGF- $\beta$ signaling in fibroblasts modulates the oncogenic potential of adjacent epithelia. Science 303, 848-851 (2004)

FURTHER READING Dvorak, H. F. Tumors: wounds that do not heal. Similarities between tumor stroma generation and wound healing. N. Engl. J. Med. 315, 1650-1659 (1986)

URLs

$\mathrm{v}-\mathrm{srC}$

http://www.ncbi.nlm.nih.gov/entrez/query.fcgi?db=gene\&cmd=Retrieve\&dopt=full_ report\&list_uids $=1491925$

breast cancer

http://www.cancer.gov/cancertopics/types/breast 